National Gas Council and the British Commereial Gas Association. He also expressed thanks to the many industrial firms for financial support, or for equipment provided either free of charge or under most favourable terms.

Dr. D. T. A. Townend (director, British Coal Utilisation Research Association, and formerly Livesey professor in the University) then gave a brief history of the Department. He paid tribute to the foresight of the late Prof. W. A. Bone, who established courses of training on such a broad basis that they were, in effect, largely chemical engineering. Any doubts there might have been about the need for chemical engineers are now completely resolved by the great and growing demand for such men and, consequently, for their training. For completion, the Leeds courses had needed more facilities for the study of unit operations; now that these were available, although the plant was most inadequately housed, the University could offer with confidence a full and balanced course in the subject.

Visitors then proceeded to the Department of Coal Gas and Fuel Industries, where the brief formal ceremony of opening the Laboratory was performed by Mr. George Brotherton-Ratcliffe, in the unavoid. able absence of $\mathrm{Mr}$. Charles F. R. Brotherton. A brief tour of inspection of the Chemical Engineering Laboratory and the Department as a whole was then made.

\section{JAPANESE EARTHQUAKE OF DECEMBER 2I, 1946}

A $\mathrm{T}$ about $04.20 \mathrm{hr}$. on December 21, 1946, an earthquake of considerable severity originated in the Pacific Ocean some 100 miles off the coast of Wakayama, Japan. The shock was recorded on seismographs throughout the world and was felt, causing some apprehension, in Tokyo. Buildings were shaken, causing damage throughout the island of Shikoku, and on much of the surrounding mainland, including the towns of Hiroshima, Kure, Kobe, Osaka, Kyoto, and Wakayama. The area severely shaken was more than 400 miles long and 150 miles wide, and railway lines were blocked throughout Shikoku. Several villages, including Singu, were severely damaged by fire caused when household fires were scattered about the wooden buildings.

The earthquake was probably accompanied by a sudden alteration of the floor of the ocean in the neighbourhood of the epicentre, because a seismic sea wave or tunami resulted, and this caused much damage around the coast. At Koshi, a coastal town with a population of 100,000 , and at nearby Takoaka, the wave was a few feet high, and in some places advanced up to five miles inland before retreating. As the wave advanced up the Kii-awadi Straits between the island of Shikoku and the mainland, it became higher until at Osaka, a coastal town with a population of $3,000,000$, it attained a height of nearly 10 feet. Kushimoto, a fishing village at the southern tip of Wakayama, was inundated, and the people of Kainan, who climbed on to their roofs and balconies after the first shock, watched the tunami roll in a few minutes later, wrecking many houses with a thunderous roar.

Altogether, the official Japanese radio report states that 1,026 people lost their lives, many more were injured and thousands of others rendered homeless. More than 1,400 fishing vessels were wrecked.
This is not the first time that a tunami has affected Osaka, lying as it does at the head of an elliptically shaped bay. One followed the great Nankaido earthquake of August 3, 1361, another on October 28, 1707, and yet a third after the Nankaido earthquake of December 24, 1854. These tunamis have a speed in some cases of as much as $30 \mathrm{ft}$. per second, and damage is thus caused by both their height and their speed. Prof. A. Imamura and others have suggested ways of mitigating disasters caused by these seismic sea waves.

The present shock had some of the characteristics of the Kwanto earthquake of September 1, 1923, but was nothing like so severe. On that occasion the first epicentre was in Sagami Bay, causing a vertical displacement of the sea bed of more than $300 \mathrm{ft}$. and a tunami $36 \mathrm{ft}$. high at the head of the Bay. Tokyo and Yokohama were largely destroyed, and the scattering of the household fires practically burned out what was left of the lower section of Tokyo and nearly all Yokohama. Nearly 100,000 people were killed. The railway bridge spanning the River Banyu-Gawa received a horizontal shaking of intensity equal to half its weight and collapsed, and the whole of the Kwanto earth block tilted a few metres, the south-east rising and the north-west sinking. As a result of the Kwanto earthquake unshipping the earthquake recorders, the Seismological Institute of Tokyo Imperial University later installed a seismograph with a minification of a half. Now, unless an earthquake has a range of motion greater than 13 in., this instrument will record it. E. TILLOTSON

\section{TIMBER DECAY AND ITS CONTROL}

T EAFLE'T No. 39 entitled "Timber Decay and its 1 Control" (Pp. 12), issued by the Forest Products Research Laboratory, Princes Risborough, com. mences by discussing the methods of growth and general appearance of fungi and the large number of spores usually produced. Since it only requires one or two spores to infect a piece of wood, means must be found to prevent spores germinating and infecting wood. Conditions of growth are then considered and the nature of the decay.

Fungal decay of wood is in reality a chemical decomposition which is brought about by the ferments and acids secreted by fungi. The wood is, as it were, digested by the fungus, and part of it is transformed into liquids which are absorbed by the fungi as nutriment. Wood in an advanced stage of decay represents the residue which is of no use to the fungus, or which has not yet been utilized. Two main types of decay in wood may be distinguished.

1. Brown Rots. In these, the wood eventually becomes a dark brown, and in the final stages tends to break up into brick-shaped pieces as a result of cracking along and across the grain. Wood severely attacked by a brown rot can be readily crumbled under the fingers. The most important decays of softwoods are 'brown rots'. Chemically speaking, brown rots are distinguished by the fact that only the cellulose and the associated carbohydrates are attacked, whereas the lignin is left practically unchanged.

2. White Rots. Darkening of the wood is sometimes the first indication of the white rot, but eventually it becomes very much lighter in colour than normal. 